\title{
PENGARUH EKSTRAK DAUN MIMBA (Azadirachta indica) TERHADAP HISTAMIN DAGING IKAN TONGKOL ABU Witria $^{\star}$, Muhammad Zainuri \\ Ilmu Kelautan, Fakultas Pertanian Universitas Trunojoyo, Universitas Trunojoyo Madura Jalan Raya Telang PO. BOX 2 Kamal, Bangkalan, Jawa Timur, Indonesia 69162
}

Diterima: 29 November 2020/Disetujui: 17 Juli 2021

*Korespondensi: witria12@gmail.com

Cara sitasi: Witria, Zainuri M. 2021. Pengaruh ekstrak daun mimba (Azadirachta indica) terhadap histamin daging ikan tongkol abu. Jurnal Pengolahan Hasil Perikanan Indonesia. 24(2): 209-217.

\begin{abstract}
Abstrak
Ikan tongkol (Thunnus tonggol) tergolong dalam famili Scrombidae yang diketahui memiliki kandungan histidina tinggi dan berpotensi menghasilkan histamin yang dapat menyebabkan keracunan bagi konsumen. Berbagai upaya dapat dilakukan untuk menurunkan kandungan histamin, salah satunya menggunakan daun mimba (Azadirachta indica). Tujuan penelitian ini adalah untuk menentukan efektivitas pemberian ekstrak daun mimba terhadap kadar histamin ikan tongkol. Ekstraksi daun mimba menggunakan metode maserasi selama 2 hari. Ikan tongkol berukuran panjang tubuh $30 \mathrm{~cm}$ yang didiamkan pada suhu ruang selama 5 jam dijadikan sebagai kontrol penelitian ini. Perlakuan yang digunakan adalah perendaman ekstrak daun mimba dengan konsentrasi 5\%, 25\%, dan 50\%. Analisis histamin menggunakan perangkat HPLC dan pengolahan data dengan program SPSS. Hasil penelitian menunjukkan kandungan histamin perlakuan kontrol, 5\%, 25\%, dan 50\% secara berurutan sebesar 60,03; 49,63; 50,54; dan 53,81 ppm. Pemberian konsentrasi ekstrak daun mimba sebesar 5\% lebih efektif untuk menghambat perkembangan kandungan histamin ikan tongkol. Konsentrasi ekstrak daun mimba sebesar 5\%, 25\%, dan 50\% secara berurutan dapat menghambat kandungan histamin ikan tongkol dengan nilai efektivitas sebesar 17,15\%, $15,80 \%$, dan $10,36 \%$.
\end{abstract}

Kata kunci : daun mimba, histamin, ikan tongkol

\section{The Effectiviness of Neem Leaves (Azadirachta indica) to Longtail Tuna Meat Histamine}

\begin{abstract}
Longtail tuna (Thunnus tonggol) as scrombidae family which has high histamine contain that can cause poisoning for consumers. Some attempts can decrease histamine contain, one of them are use mimba leaves (Azadirachta indica). The research aimed to determine the effectiveness of neem leaves extract giving towards tongkol fish histamine. Neem leaves extraction use maceration method as long as 2 days. Longtail tuna sampel that measured of length is $30 \mathrm{~cm}$ which kept on room temperature as long as 5 hours used as sample research. The used treatment was immersion of neem leaves extract with concentration 5\%, 25\%, and 50\%. Histamine analysis use HPLC device and data tabulation with SPSS program. The research result show the histamine contain of control treatment, 5\%; 25\%; and 50\% respectively was 60.03, 49.63, 50.54, and $53.81 \mathrm{ppm}$. SPSS test results has indicate that giving of $5 \%$ neem leaves extract concentration to tongkol fish is more effective to prevent the increasing of tongkol fish histamine contain. Neem leaves extract concentration which 5\%, 25\%, and 50\% respectively can decrease longtail tuna fish histamine contain with the effectiviness value was $17.15 \%, 15.80 \%$, and $10.36 \%$.
\end{abstract}

Keywords : histamine, neem leaves, longtail tuna 


\section{PENDAHULUAN}

Ikan tongkol abu (Thunnus tonggol) merupakan salah satu jenis ikan pelagis besar yang memiliki nilai ekonomis cukup tinggi. Ikan ini termasuk dalam famili Scombridae yang tersebar di seluruh perairan IndoPasifik Barat (Restiangsih dan Thomas 2018). Jumlah produksi ikan tongkol pada data Dinas Kelautan dan Perikanan Jawa Timur yaitu sebanyak $44.008,1$ ton per 2018 dan 206,1 ton per 2017 (DKP 2018). Data tersebut menunjukkan tingginya produksi ikan tongkol di Jawa Timur khususnya di Sumenep. Ikan tongkol tidak hanya memiliki rasa yang enak tapi juga memiliki kandungan protein tinggi sebesar 21,6-26,3 g/100 g (Milo et al. 2011). Ikan tongkol menjadi komoditas ekspor maupun pasar domestik yang diminati hampir semua kalangan. Kasus yang terjadi di masyarakat bahwa ikan yang tidak diolah dengan benar akan memicu perkembangan bakteri dan jika jumlahnya melebihi ambang batas dapat menyebabkan penyakit bagi konsumen. Ikan mudah mengalami pembusukan setelah mati sehingga ikan mati akan mengeluarkan senyawa-senyawa kimia yang bersifat toksik salah satunya senyawa histamin.

Senyawa histamin muncul dari aktivitas dekarboksilasi dari asam amino histidina saat ikan mulai mengalami kematian. Perombakan histidina tersebut dipercepat oleh aktivitas bakteri yang berkembang biak pada daging ikan setelah postrigor. Wei et al. (1990), mengemukakan bahwa bakteri dari famili Enterobacteriaceae banyak menghasilkan enzim histidina dekarboksilase yang menyebabkan tingginya kandungan histamin. Bakteri akan terus berkembangbiak pada kondisi lingkungan yang baik, antara lain pada suhu $25-38{ }^{\circ} \mathrm{C}$, lingkungan kumuh dan penanganan ikan yang kurang baik. Menurut Juharni (2013), semakin banyak kandungan bakteri pada ikan maka semakin tinggi pula kadar histamin yang dihasilkan. Tingginya kadar histidina dan kondisi lingkungan yang mendukung akan memicu perkembangan bakeri secara pesat dan merombak histidina menjadi histamin.

Kandungan histamin yang terlalu tinggi dan tidak dapat ditoleransi oleh tubuh akan menyebabkan keracunan. Setyarini et al. (2019), mengemukakan bahwa gejala yang timbul dari mengonsumsi histamin terlalu tinggi antara lain muntahmuntah, kerongkongan seperti terbakar, pembengkakan bibir, sakit kepala, kejang, mual, muka dan leher kemerahan, gatal-gatal, serta badan memas. Tingkat kekebalan tubuh konsumen juga menjadi faktor munculnya alergi dari histamin tersebut. The Food and Drug Administration menetapkan standar kadar histamin yang diperbolehkan yaitu 5 mg/100 g (50 ppm) (FDA 2011). Uni Eropa menetapkan kadar histamin rata-rata pada ikan tidak boleh lebih dari $10 \mathrm{mg} / 100 \mathrm{~g}$ (100 ppm). Pencegahan terhadap timbulnya keracunan dapat dilakukan apabila diketahui kadar histamin dan penyebab pertumbuhan histamin. Oleh sebab itu, penting dilakukan penelitian terkait kadar histamin pada ikan khususnya ikan tongkol yang sering menjadi kasus keracunan di masyarakat.

Hiruma et al. (2020) mengemukakan bahwa kadar histamin tidak bisa menurun dengan proses pemasakan, pengalengan ataupun pembekuan karena sifat histamin stabil pada panas. Menurut Astuti dan Asniati (2018), pemberian ekstrak daun belimbing wuluh terhadap kandungan histamin ikan cakalang (Katsuwonus pelamis) mampu menghambat pertumbuhan histamin ikan cakalang namun harus dilakukan penelitian lebih lanjut karena dalam uji statistik belum diketahui hasil yang berbeda nyata. Menurut Prasetiawan et al. (2013) sampel ikan tongkol yang telah diberi perlakuan kuersetin disimpan pada suhu ruang selama 36 jam mampu mencegah peningkatan histamin. Penelitian ini memanfaatkan ekstrak daun mimba dengan beberapa konsentrasi untuk menghambat pertumbuhan histamin.

Pulau Madura memiliki tanaman mimba yang sangat melimpah dan hampir setiap rumah menanam tanaman mimba untuk pagar rumah. Masyarakat biasanya memanfaatkan daun mimba untuk mengobati gatal-gatal. Penelitian ekstrak daun mimba sebagai pengawet tomat efektif sebagai pengawet alami dengan konsentrasi 8\% (Cahyaningsih dan Putu 2020). Daun mimba (Azadirachta indica) mengandung senyawa flavonoid (kuersetin 
dan rutin), alkaloid, saponin, tanin, nimbidin. Senyawa tersebut sebagai antibakteri yang dapat menghambat aktivitas bakteri positif maupun negatif termasuk bakteri pembentuk histamin (Ayini et al. 2014). Menurut Supriyanto et al. (2017) dalam penelitiannya bahwa maserasi daun mimba dengan pelarut air, etanol $60 \%$, etanol $80 \%$, metanol $60 \%$, dan metanol 80\% diketahui dapat mengekstrak senyawa flavonoid. Kebermanfaatan hasil penelitian dapat dikembangkan di masyarakat khususnya Madura yang memiliki potensi daun mimba cukup melimpah dan ikan tongkol sebagai produk hasil perikanan di Kabupaten Sumenep. Tujuan penelitian ini adalah untuk menentukan efektivitas pemberian ekstak daun mimba terhadap kadar histamin ikan tongkol

\section{BAHAN DAN METODE Bahan dan Alat}

Bahan yang digunakan antara lain daun mimbayang dipetikdidaerahpesisir Bangkalan Madura, sampel ikan tongkol abu dari Tempat Pelelangan Ikan Branta Pamekasan Madura, larutan standar histamin $10 \mathrm{mg} / \mathrm{L}$ (Merck), metanol $75 \%$, asetonitril, natrium dihirogen fosfat $10 \mathrm{mM}$ (Merck), natrium hidroksida 1N (Merck), Ultra Pure Water (UPW), dan Orto-ftalatdikaboksilaldehid (OPT) 0,1\%. Alat yang digunakan antara lain unit HPLC Agilent 1200 series, homogenizer/blender, tip pipet dan mikropipet (Socorex Acura 825, Accu jet), timbangan analitik ketelitian 0,01 g (Tanita), tabung sentrifuge polipropilena, pencampur pusar/vortex mixer (Barnstead type 37600), labu erlenmeyer (Schott Duran), freezer (Barnstead), sentrifuge Rotofix 32A dan evaporator putar (Bucchi tipe R215).

\section{Metode Penelitian Pembuatan ekstrak daun mimba}

Ekstraksi daun mimba dilakukan untuk mendapat senyawa aktifnya. Daun mimba dipetik dari pohonnya, pemilihan daun mimba diutamakan berwarna hijau segar, tidak terlalu muda atau tua, kenampakan baik dan tidak cacat. Daun yang telah dipetik dilakukan pencucian dengan air mengalir untuk membersihkan dari hewan dan kotoran. Kemudian dikeringkan pada suhu ruang selama 3 hari dan dipotong menjadi lebih kecil kurang dari $2 \mathrm{~cm}$. Daun yang setengah kering dihaluskan menggunakan blender sampai daun berukuran seperti serbuk. Serbuk daun mimba ditimbang dan dimasukkan dalam tabung tertutup untuk dilakukan maserasi. Proses maserasi dilakukan menggunakan pelarut akuades dengan perbandingan daun mimba dan pelarut 1:5 selama 2 hari. Ekstrak hasil maserasi selanjutnya dilakukan penyaringan menggunakan kain mori. Filtrat cair diuapkan dengan evaporator suhu $60{ }^{\circ} \mathrm{C}$. Hasil ekstrak daun mimba diencerkan dengan akuades pada konsentrasi 5\%, 25\%, dan 50\%.

\section{Penelitian tahap pertama}

Uji pendahuluan dilakukan untuk mengetahui morfometrik ikan, kesegaran dan kadar histamin. Sampel ikan tongkol setelah diukur suhu, panjang tubuh, dan bobotnya, kemudian dilakukan uji organoleptik. Pegecekan suhu dilakukan menggunakan termometer yang ditembakkan pada tubuh ikan. Pengukuran panjang dilakukan dengan mengukur panjang total ikan tongkol dari ujung mulut sampai pangkal sirip. Bobot ikan diukur dengan menimbang ikan dengan timbangan analitik. Uji organoleptik dilakukan oleh 2 orang panelis yang sudah dilatih untuk menganalisis mutu ikan terdiri dari kondisi mata, insang, lendir, daging, bau dan tekstur. Uji ini menggunakan indra manusia dan memberi skor mutu ikan dari hasil kerja indra tersebut sesuai SNI mutu ikan segar.

Sampel ikan tongkol yang telah diketahui panjang, bobot dan nilai organoleptiknya lalu disiangi dengan memisahkan daging dari isi perut, kepala, kulit, dan tulang. Daging ditimbang kurang lebih 50 g sebanyak 3 potong. Daging diberi 3 perlakuan yaitu: A langsung diberi es, B didiamkan pada suhu ruang selama 2,5 jam dan C didiamkan pada suhu ruang selama 5 jam. Selain suhu, perlakuan lama penyimpanan juga diberikan dengan harapan mendapatkan hasil kadar histamin yang bisa dijadikan sebagai standar untuk uji lanjutan dengan mempertimbangkan bahwa kadar histamin akan terbentuk seiring lamanya waktu penyimpanan. Daging ikan dimasukkan dalam stirofoam berisi es lalu dibawa ke laboratorium Pengujian Mutu 
dan Pengembangan Produk Kelautan dan Perikanan (PMP2KP) untuk pengujian histamin. Hasil uji kandungan histamin yang tertinggi akan dijadikan sebagai acuan perlakuan pada uji histamin ikan tongkol sebelum diberi perlakuan daun mimba.

\section{Penelitian tahap kedua}

Ikan tongkol didapatkan dari nelayan lalu dimasukkan dalam boks berisi es batu/ es curai untuk menjaga suhu ikan selama perjalanan. Ikan tongkol disimpan di laboratorium Pengelolaan Sumberdaya Perikanan dan dimasukkan dalam pembeku (freezer) untuk meminimalisasi aktivitas bakteri dan kontaminan. Ikan tongkol yang akan dianalisis, dikeluarkan dari pembeku dan didiamkan pada suhu ruang selama 5 jam lalu dilakukan uji organoleptik ikan segar berdasarkan SNI 01-2346-2006 (BSN 2006). Ikan didiamkan selama 5 jam pada suhu ruang berdasarkan hasil penelitan tahap pertama yang menghasilkan kadar histamin tinggi menuju batas standar yaitu hampir 100 ppm. Ikan juga diukur suhu, panjang dan bobot serta organoleptik ikan. Setelah dilakukan pengujian/penskoran, ikan tongkol langsung dihilangkan bagian kepala, tulang dan isi perut lalu daging diblender agar dugaan histamin pada bagian tertentu daging ikan dapat merata pada seluruh daging. Daging ikan tongkol dibagi menjadi 4 bagian dan ditimbang kurang lebih $50 \mathrm{~g}$ untuk tiap perlakuan. Masingmasing $50 \mathrm{~g}$ daging ikan tongkol dari 6 ekor sebagai pengulangan direndam dalam larutan ekstrak daun mimba yang telah disiapkan masing-masing $100 \mathrm{~mL}$ untuk setiap sampel. Pada proses perendaman daging ikan tongkol dibungkus dengan kain mori untuk mencegah pencampuran daging dengan larutan ekstrak daun mimba. Daging ikan sampel direndam dengan larutan ekstrak daun mimba dengan perlakuan sebagai berikut :

1 : sebagai kontrol dengan pemberian ekstrak daun mimba $0 \%$

2 : pemberian ekstrak daun mimba 5\%

3 : pemberian ekstrak daun mimba $25 \%$

4 : pemberian ekstrak daun mimba 50\%

Perendaman dengan ekstrak daun mimba dilakukan selama 20 menit. Kemudian sampel disimpan sebelum dilakukan preparasi uji histamin. Pada penelitian ini daging ikan tongkol langsung disimpan di dalam pembeku setelah direndam ekstrak daun mimba.

\section{Analisis histamin}

Analisis histamin menggunakan perangkat HPLC Agilent Technologies 1200 series. Prosedur analisis histamin meliputi preparasi sampel, pembuatan reagen, dan pembacaan dengan HPLC. Analisis histamin mengacu pada panduan manual pengujian histamin dengan HPLC oleh PMP2KP. HPLC yang akan digunakan untuk menganalisis dilakukan pengecekan dan pengaturan terlebih dahulu hingga kondisi HPLC baik dan siap digunakan. Menurut Sulistiawati (2014), dalam penelitiannya uji histamin dengan metode pengujian HPLC meliputi tahapan preparasi sampel, pembuatan reagen, dan tahap derivatisasi oleh perangkat HPLC.

\section{Analisis Data}

Penelitian ini menggunakan rancangan percobaan berupa rancangan acak lengkap faktor tunggal dengan 6 kali ulangan. Hasil analisis kadar histamin pada 24 sampel daging ikan tongkol yang telah diberi perlakuan ekstrak daun mimba selanjutnya dianalisis sidik ragam ANOVA dengan program SPSS dan Microsoft Excel.

\section{HASIL DAN PEMBAHASAN Ekstrak Daun Mimba}

Ekstraksi daun mimba kering sebanyak 398,3 g menghasilkan 80 mL ekstrak dengan tekstur sedikit kental dan berwarna cokelat tua. Berdasarkan penelitian Soraya dan Sunnati (2019), pengeringan $1,5 \mathrm{~kg}$ daun mimba diperoleh $285 \mathrm{~g}$ serbuk hasil ekstrak $58 \mathrm{~g}$. Ekstrak daun mimba digunakan sebagai perlakuan untuk ikan tongkol, apabila ekstrak daun mimba belum digunakan untuk perlakuan ikan, ekstrak daun mimba disimpan dalam lemari pendingin. Ekstrak daun mimba diencerkan dengan akuades menjadi tiga konsentrasi, yaitu 5\%, 25\% dan $50 \%$. Masing-masing larutan ini dimasukkan dalam 24 wadah yang akan digunakan utuk merendam daging tongkol. 


\section{Kadar Histamin Ikan Tongkol}

Ikan tongkol (Figure 1) yang digunakan sebagai uji pendahuluan dengan panjang 29,5 $\mathrm{cm}$, bobot $343,1 \mathrm{~g}$ dan suhu $12,5^{\circ} \mathrm{C}$ memiliki tingkat kesegaran rata-rata $6,6 \pm 0,6$ pada hasil uji organoleptik. Pengukuran kadar histamin dari tiga sampel daging ikan tongkol positif mengandung histamin. Kadar histamin dapat dilihat pada Table 1.

Table 1 Preliminary test histamine at room temperature treatment

\begin{tabular}{cr}
\hline $\begin{array}{c}\text { Treatment } \\
\text { (hours) }\end{array}$ & $\begin{array}{c}\text { Histamine level } \\
\text { (ppm) }\end{array}$ \\
\hline 0 & 77.09 \\
2.5 & 56.55 \\
5 & 95.38 \\
\hline
\end{tabular}

Berdasarkan Table 1 bahwa perlakuan waktu penyimpanan ikan tongkol pada suhu ruang memengaruhi kadar histamin ikan tongkol. Kandungan histamin tertinggi pada perlakuan 5 jam sebesar 95,38 ppm dan terendah 2,5 jam sebesar 56,55 ppm. Kadar histamin dengan 0 jam perlakuan suhu ruang sebesar 77,09 ppm. Kadar histamin dari ketiga sampel masih dibawah 100 ppm sehingga aman untuk dikonsumsi. Berdasarkan hasil uji pendahuluan perlakuan 5 jam mengandung kadar histamin tertinggi, maka nilai tersebut dijadikan sebagai acuan untuk uji lanjutan. Uji selanjutnya ikan tongkol didiamkan pada suhu ruang selama 5 jam. Junaedi et al. (2020) menyatakan bahwa bakteri akan mengontaminasi ikan setelah mati pada bagian permukaan, insang dan isi perut, lalu akan menyerang daging pada kondisi postrigor. Bakteri berperan sebagai pendegradasi protein pada daging ikan tongkol sehingga proses terbentuknya histamin semakin cepat. Semakin lama ikan mati dan lingkungan yang mendukung perkembangan bakteri maka semakin tinggi histamin yang dihasilkan. Data pada uji pendahuluan terdapat ketidaksinkronan hubungan lama waktu pendiaman di suhu ruang dengan kadar histamin disebabkan oleh daging tidak digiling sehingga kadar histamin pada setiap bagian tubuh ikan tidak tercampur rata. Menurut Wodi et al. (2018), kadar histamin daging ikan tuna pada bagian perut, punggung, dan ekor berbeda yaitu pada perlakuan hari ke-0 kadar histamin pada perut 3,05 ppm, punggung 4,05 ppm, dan ekor $3,46 \mathrm{ppm}$.

\section{Suhu dan Kesegaran Ikan Tongkol}

Ikan tongkol sampel memiliki ukuran hampir sama yaitu panjang rata-rata $30 \mathrm{~cm}$ dan berat rata-rata 346,16 g. Sampel yang digunakan sebanyak 6 ekor sebagai ulangan. Rata-rata suhu ikan tongkol setelah didiamkan 5 jam pada suhu ruang sebesar $23,9 \pm 0,5{ }^{\circ} \mathrm{C}$. Suhu masing-masing ikan berbeda pada setiap ulangan, hal ini disebabkan oleh pengaruh suhu lingkungan dan suhu awal ikan itu sendiri. Menurut Radjawane et al. (2016), penurunan kesegaran mutu ikan disebabkan oleh berbagai faktor, salah satunya suhu yang memliki peranan penting dalam penyimpanan. Menurut Sitakar et al. (2016), semakin tinggi suhu penyimpanan dan lama

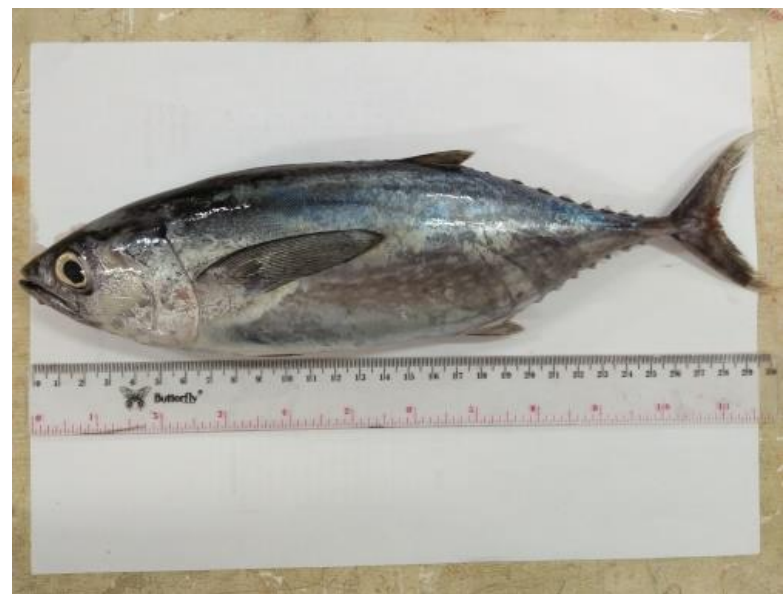

Figure 1 Longtail tuna (Thunnus tonggol) 
waktu penyimpanan berpengaruh nyata pada jumlah bakteri, sehingga ikan yang disimpan pada suhu ruang sekitar $27^{\circ} \mathrm{C}$ dapat memicu perkembangan bakteri dengan cepat.

Uji organoleptik sampel ikan tongkol bertujuan untuk mengetahui mutu kesegaran ikan tongkol berdasarkan SNI 01-2346-2006 (BSN 2006). Proses uji dilakukan dengan indera manusia berupa penglihatan, pembau, dan peraba. Bagian ikan yang diuji antara lain mata, insang, lendir, daging, bau, dan tekstur. Adapun pemberian skor dilakukan berdasarkan kriteria ikan dari nilai 1 sampai 9. Ikan dianggap segar apabila rata-rata nilai organoleptiknya diatas 7. Hasil uji organoleptik sampel ikan tongkol disajikan pada Table 2.

Table 2 Longtail Tuna Organoleptic Test

\begin{tabular}{cr}
\hline Parameter & \multicolumn{1}{l}{ Result } \\
\hline Eyes & $6.5 \pm 0.55$ \\
Gills & $5.83 \pm 1.72$ \\
Mucus & $6.00 \pm 0.00$ \\
Flesh & $5.33 \pm 0.82$ \\
Smell & $6.00 \pm 0.00$ \\
Texture & $6.50 \pm 0.55$ \\
\hline
\end{tabular}

Hasil organoleptik berkisar 5-6, hasil tersebut menunjukkan bahwa ikan sudah mulai mengalami kemunduran mutu. Menurut Apriani et al. (2017), nilai organoleptik ikan tinggi pada pagi hari pascatangkap dan menurun setelah sore hari. Penurunan nilai organoleptik ikan disebabkan proses kimiawi dan mikrobiologi pada ikan. Proses kimiawi misalnya penguraian lemak dan protein dapat memengaruhi bau, tekstur, dan rasa. Mikroba juga berperan aktif dalam proses penguraian protein dan lemak.

\section{Kadar Histamin}

Histamin diekstrak dari jaringan daging sampel ikan tongkol menggunakan metanol $75 \%$ selanjutnya diderivatisasi dengan senyawa orto-ftalatdikaboksilaldehid (OPT). Kadar histamin dapat diketahui setelah diukur secara HPLC dengan detektor fluoresens. Nilai rata-rata kadar histamin dengan satuan ppm dapat diamati pada Figure 2.

Kadar histamin terendah pada hasil uji terdapat pada konsentrasi 5\% dan rata-rata tertinggi terdapat pada perlakuan kontrol. Hasil analisis sidik ragam menunjukkan bahwa ekstrak daun mimba efektif dapat menghambat pembentukan histamin. Hal ini terbukti, bahwa perlakuan 5 dan $25 \%$ ekstrak daun mimba berbeda nyata menurunkan kadar histamin dibandingkan dengan kontrol. Persentase efektivitas pengaruh ekstrak daun mimba terhadap kadar histamin dapat diamati pada Figure 3. Perhitungan ini diperoleh dari perbandingan rata-rata kadar histamin pada masing-masing perlakuan dengan kontrol dikali 100\% (tersaji pada Figure 3).

Figure 3 memperlihatkan bahwa tingkat efektivitas pemberian ekstrak daun mimba terhadap penurunan histamin dengan perlakuan 5\% sebesar $17,15 \%$, perlakuan $25 \%$ sebesar $15,80 \%$, dan perlakuan $50 \%$ sebesar $10,36 \%$. Ayini et al. (2014) melaporkan bahwa adanya senyawa alkaloid, flavonoid, saponin, dan pufenol yang bersifat antibakteri dapat menghambat aktivitas bakteri pembentuk histamin. Raju et al. (2015) melaporkan bahwa indol alkaloid memiliki sifat analgesik, antialergi, antikonvulsan, antijamur, antihistamin, anti-inflamasi, antikanker, antihipertensi, kardiovaskular, antioksidan. Ketiga perlakuan ekstrak daun mimba yang diketahui, bahwa konsentrasi ekstrak daun

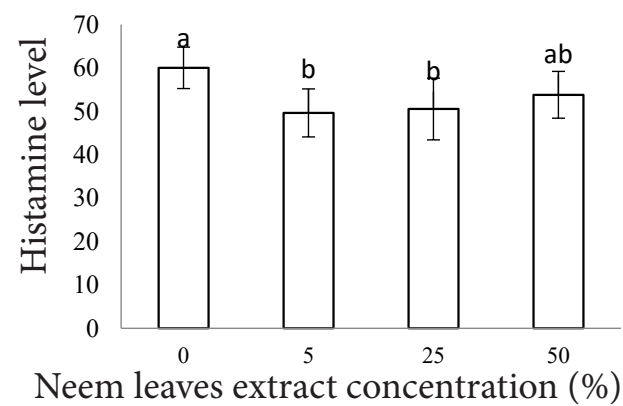

Figure 2 Average histamine level of longtail tuna 


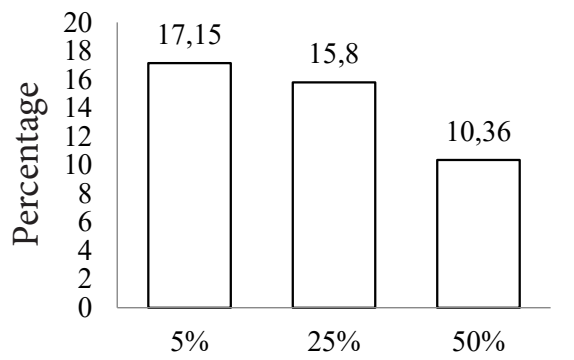

Neem leaves extract concentration

Figure 3 Effectiveness of neem leaves extract in decreasing histamine level

mimba 5\% lebih efektif untuk menghambat kadar histamin yang terkandung pada ikan tongkol. Perlakuan $25 \%$ dan $50 \%$ diduga mengalami prooksidan yang berasal dari terakumulasinya antioksidan sehingga menyebabkan nilai kandungan histamin menjadi lebih tinggi. Puspasari et al. (2017), memaparkan bahwa semakin tinggi konsentrasi ekstrak yang mengandung antioksidan maka semakin besar kandungan antioksidannya serta diikuti semakin besar juga kandungan prooksidannya. Berdasarkan hasil analisis tersebut, maka pada tingkatan pemanfaatan untuk menghambat kadar histamin ikan tongkol cukup menggunakan daun mimba dengan konsentrasi 5\%. Hasil penelitian ini dapat digunakan oleh masyarakat dalam menghambat perkembangan histamin pada ikan tongkol cukup dengan konsentrasi $5 \%$.

Susmitha et al. (2013) menyatakan bahwa kandungan fitokimia pada daun mimba antara lain kuersetin, alkaloid, steroid, flavonoid, saponin, dan tanin. Senyawa tersebut dapat menghambat pertumbuhan bakteri Salmonella dan E. coli. Menurut Prasetiawan et al. (2013), pemberian kuersetin dapat menghambat penambahan histamin selama penyimpanan 36 jam. Kuersetin dapat menghambat bakteri pembentuk histamin antara lain dari spesies Staphylococcus aureus (de-Souza et al. 2010), Enterobacter aerogenes (Sannomiya et al. 2005), Escherichia coli (Sandhar et al. 2011), Klebsiella pneumoniae (Aziz et al. 1998), Enterobacter cloacae, Clostridium perfringens (Lee dan Kim 2002).

Penelitian lanjutan yang perlu dilakukan yaitu untuk mengetahui kadar kuersetin pada ekstrak daun mimba. Selain itu, perlu juga diidentifikasi jenis bakteri pembentuk histamin yang dapat dihambat dengan ekstrak daun mimba. Harapannya untuk penelitian selanjutnya dapat diaplikasikan secara langsung beserta kadar histamin ikan sebelum dikonsumsi dan setelah direndam dengan ekstrak daun mimba.

\section{KESIMPULAN}

Perlakuan ekstrak daun mimba pada ikan tongkol efektif menghambat perkembangan kadar histamin. Kadar histamin sampel ikan tongkol yang telah diberi perlakuan ekstrak daun mimba masih aman dengan kadar histamin di bawah 100 ppm. Tingkat efektivitas terbaik pada ekstrak daun mimba dengan konsentrasi 5\% mampu menghambat kadar histamin sebesar 17,15\%.

\section{UCAPAN TERIMA KASIH}

Ucapan terimakasih disampaikan pada UPT Pengujian Mutu dan Pengembangan Produk Kelautan dan Perikanan (PMP2KP) yang telah membantu menyelesaikan penelitian ini

\section{DAFTAR PUSTAKA}

Apriani R, Ferasyi TR, Razali. 2017. Jumlah cemaran mikroba dan nilai organoleptik ikan tongkol (Euthynnus affinis). Jurnal Ilmiah Mahasiswa Veteriner. 1(3): 598603.

Astuti I, Asniati N. 2018. Pengaruh ekstrak daun belimbing wuluh terhadap histamin pada ikan cakalang (Katsuwonus pelamis). Gorontalo Fisheries Journal. 1(2): 1-9.

Ayini U, Siti HB, Titis CD. 2014. Efek antibakteri ekstrak daun mimba (Azadirachta indica A. Juss) terhadap 
bakteri Vibrio algynoliticus secara in vitro. Journal of Biology \& Biology Education. 6(1): 67-75.

Aziz NH, Farag SE, Mousa LA, Abozaid MA. 1998. Comparative antibacterial and antifungal eff ect of some phenolic compounds. Microbios. 93(374): 43-45.

[BSN] Badan Standardisasi Nasional. 2006. Petunjuk pengujian organoleptik dan atau sensori. SNI 01-2346.2006. Jakarta (ID): Badan Standardisasi Nasional.

Cahyaningsih E, Putu ESKY. 2020. Uji aktivitas ekstrak daun mimba (Azadirachta indica A. Juss) sebagai bahan pengawet alami buah tomat. Jurnal Ilmiah Medicamento. 6(2): 118-122. de-Souza L, Wahidulla S, Devi P. 2010. Antibacterial phenolic from the mangrove Lumnitzera racemosa. Indian Journal of Marine Science. 39(2): 294-298.

[DKP] Dinas Kelautan dan Perikanan Provinsi Jawa Timur. 2018. Form Laut Triwulan 2018. Surabaya: DKP Jatim.

[FDA] Food and Drug Administration. 2011. Scombrotoxin (Histamine) formation di dalam: Fish and Fishery Product Hazards and Control Guide. Washington: Departemen of Health and Human Service, Center for Food Safety and Applied Nutrition.

Hiruma S, Ishihar $M$, Nakamura $S$, Sato Y, Asahina H, Fukuda K, Takayama T, Murakami K, Yokoe H. 2020. Bioshell calcium oxide-containing liquids as a sanitizer for the reduction of histamine production in Raw Japanese Pilchard, Japanese Horse Mackerel, and Chub Mackerel. Foods. 9(7): 1-12.

Juharni J. 2013. Pengaruh konsentrasi garam dan lama fermentasi terhadap kadar histamin peda ikan kembung perempuan (Rastrelinger nelectus). Agrikan: Jurnal Ilmiah Agribisnis dan Perikanan. 6(1): 7380.

Junaedi AS, Riana F, Sari HCP, Witria, Zainuri M. 2020. Kualitas daging ikan kurisi (Nemipterus japonicus) hasil tangkapan Branta Fishing Port, Pamekasan. Jurnal Pengolahan Hasil Perikanan Indonesia. 23(2): 303-319.

Lee HS, Kim MJ. 2002. Selective responses of three ginkgo biloba leaf-derived constituents on human intestinal bacteria. Journal of Agricultural and Food Chemistry. 50: 1840-1844.

Milo MS, Ekawati LM, Pranata FS. 2011. Mutu ikan tongkol (Euthynnus affinis) di Kabupaten Gunung Kidul dan Sleman Daerah Istimewa Yogyakarta (ID): Fakultas Teknobiologi Universitas Atma Jaya Yogyakarta.

Prasetiawan NR, Agustini TW, Farid W. 2013. Penghambatan pembentukan histamin pada daging ikan tongkol (Euthynnus affinis) oleh quercetin selama penyimpanan histamine inhibition on mackerel (Euthynus affinis) flesh by using quercetine during storage. Jurnal Pengolahan Hasil Perikanan Indonesia. 16(2): 150-158.

Puspasari AR, Eko ND, Laras R. 2016. Aplikasi antioksidan dari ekstrak lamun (Cymodocea rotundata) pada minyak ikan tongkol (Euthynnus affinis). Agritech. 37(2): 115-120.

Radjawane C, Darmanto YS, Swastawati F. 2016. Kajian kandungan histamin ikan cakalang (Katsuwonus pelamis) segar dan asap pada sentral pengolahan ikan asap Di Kota Ambon. Prosiding Seminar Nasional Kelautan Universitas Trunojoyo Madura, pp. 316-320.

Raju GN, Sai KB, Meghana MS, Chandana K, Suresh PV,Nadendla RR. 2015. Synthesis, Characterization and Biological Activity of Indole-2-carboxylic acide derivatives. International Journal of Pharmaceutical Chemistry. 5: 202- 206.

Restiangsih YH, Thomas H. 2018. Analisis pertumbuhan dan laju eksploitasi ikan tongkol abu, Thunnus tonggol (Bleeker,1851) di Perairan Laut Jawa. Bawal. 10(2): 111-120.

Sandhar HK, Kumar B, Prasher S, Tiwari P, Salhan M, Sharma P. 2011. A review of phytochemistry and pharmacology of flavonoids. International Pharmaceutica Sciencia. 1(1): 25-41.

Sannomiya M, Michelin DC, Rodrigues CM, Santos LC, Salgado HRN, HirumaLima CA, Brito ARSM, Vilegas W. 2005. Byrsonima Crassa Niedenzu (IK): 
Antimicrobial activity and chemical study. Journal of Basic and Applied Pharmaceutical Science. 26(1): 71-75.

Setyarini VD, Indah L, Christ K. 2019. Kadar histamin pada udang vannamei (Litopenaeus vannamei) dan identifikasi bakteri pembentuk histamin. Analis Kesehatan Sains. 8(1): 666-671.

Sitakar NM, Jamin, Faisal A, Mahdi M, Zakiah HNS. 2016. Pengaruh suhu pemeliharaan dan masa simpan daging ikan nila (Oreochromis niloticus) pada penyimpanan suhu $-20{ }^{\circ} \mathrm{C}$ terhadap jumlah total bakteri. Jurnal Medika Veterinaria. 10(2): 162-165.

Soraya C, Sunnati FW. 2019. Efek antibakteri ekstrak daun mimba (Azadirachta indica) terhadap pertumbuhan Enterococcus faecalis secara in-vitro. Cakradonya Dent Journal. 11(1). 23-32.

Sulistiawati S. 2014. Analisis histamin pada berbagai jenis ikan pelagis dengan metode High Performance Liquid
Chromatography (HPLC). [Skripsi]. Pangkep: Politeknik Pertanian Negeri Pangkajene dan Kepulauan.

Supriyanto, Simon BW, Rifa IM, Yunianta.2017. Uji fitokimia dan aktivitas antioksidan ekstrak daun mimba (Azadirachta indica Juss). Prosiding SNATIF ke-4. 523-529.

Susmitha S, Vidyamol KK, Ranganayaki P, Vijayaragavan R. 2013. Phytochemical extraction and antimicrobial properties of Azadirachta indica (neem). Global Journal of Pharmacology. 7(3): 316-320.

Wei CI, Chen JA, Koburger JA, Otwell WS, Marshall MR. 1990. Bacterial growth and histamine production on vacuum packaged tuna. Jurnal Food Sciene. 55: 5963.

Wodi SIM, Wini T, Mala N. 2018. Histamin dan identifikasi bakteri pembentuk histamin pada tuna mata besar (Thunnus obesus). Jurnal Teknologi Perikanan dan Kelautan. 9 (2): 185-192. 